\title{
Comparison of Leprosy Ophthalmic Symptoms in Three Leprosaria in Japan (North, Middle and South)
}

\author{
KIKUO HAYASHI \\ National Leprosarium Tama Zenshoen \\ (Director Yoshikazu Yajima)
}

The present report describes the comparison of ophthalmic symptoms of lprosy observed in 3 leprosaria in Japan (notrth, middle and south). Ophthalmic symptoms of leprosy in the north leprosarium were more severe than those in the south leprosarium. Furthermore, in the case of the leprosy patients born in the same district, those who lived in the north leprosarium were more severe than those in the south leprosarium. Details were as follow:

1. Comparison of the depilation of eyebrow of L. type $82 \%$ in the north, $65 \%$ in the middle $56 \%$ in the south

2. Comparison of the Uveitis of L. type $74 \%$ in the north, $66 \%$ in the middle $47 \%$ in the south

3. Comparison of the secondary cataract of L. type

$23 \%$ in the north, $20 \%$ in the middle $11 \%$ in the south

4. Comparison of Opacit.s Cornea

$23 \%$ in the north, $19 \%$ in the middle $13 \%$ in the south

5. Comparison of Lagophthalmus $47 \%$ in the north, $38 \%$ in the middle $25 \%$ in the sonth

6. Percentage of Lagophthalmus of L. type was higher than that of tuberculoid type. 


\title{
三療養所入園患者の眼症状の比較
}

\author{
林喜 久 夫 \\ 多磨全生園 （園長 矢嶋良一博士） \\ （この㻭告の要旨は昭和37年符35回癞学会に於いて発表した。） \\ (昭和 39 年 5 月 26 日受付)
}

嬾の氛候説については, 既に林(文) ${ }^{1)}$, 光田 ${ }^{2)}$ 等の報 告があり, 醏沼 ${ }^{3)}$ も瀬眼の気候的影響について詳述して いる。

偶々著者は, 比較的答冷地にある草津萡泉園, 混暖な 庇児島に位置する星塚敬愛園, 及び巠熱湍に属する奄美 和光園の三療鉴所の患者の眼症状を比較観察する機会に 恵まれ，癩眼症状が気候により如何に左右されるか，

又, 同一出身地の患者が，南北の療鉒所に別れ住んだ埸 合，その症状が如何に推移するかを同時に調查したの で，これらにつき，此処に報告する次第である。

\section{成 績}

I . 三園患者の比較

1) 対象患者 病型及び出身地の調查は, 三園共, 全 入園患者について行なったが, 眼症状の調査は, 楽泉園 866名, 敬愛園 956名, 和光園 241名についてのものであ る。

2 ）三園の患者出身地及び病型 三園の患者出身地は 表 I の椂で, 楽沗園の患者は関東以北の出身者が, 大部

表 I 三園の患者出身地

\begin{tabular}{|c|c|c|c|c|c|c|c|}
\hline & 楽 & 永 & 園 & & 敬 & 愛 & 園 \\
\hline 群 & 馬 & 県 & $27.3 \%$ & \multirow{2}{*}{\multicolumn{3}{|c|}{$\begin{array}{l}\text { 鹿 罗島 県 } \\
\text { （大帠郡 }\end{array}$}} & $52.1 \%$ \\
\hline 東 & 京 & 都 & $8.4 \%$ & & & & $12.5 \%)$ \\
\hline 新 & 鼬 & 県 & $7.1 \%$ & 宮 & 崎 & 県 & $21.8 \%$ \\
\hline 杤 & 木 & 眞 & $5.7 \%$ & 沖 & & 縄 & $5.9 \%$ \\
\hline 朝 & & 鮮 & $5.0 \%$ & 長 & 崎 & 県 & $4.6 \%$ \\
\hline 長 & 野 & 県 & $4.3 \%$ & 熊 & 本 & 県 & $3.8 \%$ \\
\hline 愛 & 知 & 県 & $3.7 \%$ & 朝 & & 鮮 & $2.1 \%$ \\
\hline 秋 & 田 & 県 & $3.4 \%$ & そ & の & 他 & $9.7 \%$ \\
\hline 天 & 阪 & 府 & $2.3 \%$ & & & & \\
\hline 福 & 䦓 & 県 & $2.2 \%$ & & 和 & 光 & 園 \\
\hline 茨 & 城 & 県 & $2.2 \%$ & 大 & 島 & 郡 & $93 \%$ \\
\hline 埼 & 玉 & 県 & $2.2 \%$ & 本 & & 州 & $5 \%$ \\
\hline そ & の & 他 & $26.2 \%$ & 沖 & & 絽 & $2 \%$ \\
\hline
\end{tabular}

表II 三園患者の病型

\begin{tabular}{l|c|c|c}
\hline & 楽泉 園 & 敬愛園 & 和 光 園 \\
\hline 結 節 型 & $74 \%$ & $62 \%$ & $56 \%$ \\
斑 紋 型 & $2 \%$ & $12 \%$ & $8 \%$ \\
神 経 型 & $23 \%$ & $26 \%$ & $36 \%$ \\
不 定 型 & $1 \%$ & $0 \%$ & $0 \%$ \\
\hline
\end{tabular}

分を占め, 敬愛園の患者は九州南部の者が大部分であり, 和光園の患者はその $95 \%$ 迄が奄美以南の出身者である。 病型は表 IIの様に，染泉園の結節型74\%に対し，敬愛 園, 和光罦の順に結節型が少くなり，それにつれて神斑 型が増えている。

3）結節型患者の眉毛脱落頻度 表而の様に, 楽泉園 の患者では，眉毛の健全な者は20\%に達しないのに対し 表吕 三園患者の眉毛脱落頻度

\begin{tabular}{|c|c|c|c|c|}
\hline & & 㴡 泉 園 & 敬 愛園 & 和 光 園 \\
\hline 脱 & 落 & $73 \%$ & $60 \%$ & $29 \%$ \\
\hline 粗 & 鬆 & $9 \%$ & $5 \%$ & $27 \%$ \\
\hline 健 & 全 & $18 \%$ & $35 \%$ & $44 \%$ \\
\hline
\end{tabular}

て, 敬愛園, 和光園の患者では, $40 \%$ 前後が健全であっ た。

4）結節型患者の策萄膜炎及び併発性白内障頻度 表 $\mathrm{IV}$ の様に，楽泉園では $3 / 4$ の忠者に盏萄膜炎の既往があっ たが，和光園では罹忠者は半数にも満たなかった。又表 $\mathrm{V}$ の様に，楽泉園，敬愛園共に20\%以上の患者が併発性 白内障の既往があったにも拘わらず，和光園では僅か10 \%程度でしかなかった。

表IV 葡萄膜炎頻度

\begin{tabular}{lr|c|c|c}
\hline & & 楽 泉 園 & 敬 愛園 & 和 光 園 \\
\hline 䍜 & 患 & $74 \%$ & $66 \%$ & $47 \%$ \\
来䍜 & 患 & $26 \%$ & $34 \%$ & $53 \%$ \\
\hline
\end{tabular}


表 V 併発性白内障頻度（眼数）

\begin{tabular}{|c|c|c|c|}
\hline & 楽 泉園 & 敬 愛 園 & 和 光 園 \\
\hline 白 内 障 & $23 \%$ & $20 \%$ & $11 \%$ \\
\hline 健 & $77 \%$ & $80 \%$ & $89 \%$ \\
\hline
\end{tabular}

5 ）鬼眼頻度表 VIの様に, 鬼眼も又, 北の療養所程 頻度が高く, 楽泉園では50\%近くが兔眼症であったが, 表 VI 兔 眼 頻 度

\begin{tabular}{cc|c|c|c}
\hline & & 楽泉 園 & 敬 愛 園 & 和 光 園 \\
\hline 両 & 側 & $30 \%$ & $25 \%$ & $16 \%$ \\
片 & 侧 & $17 \%$ & $13 \%$ & $9 \%$ \\
健 & 全 & $53 \%$ & $62 \%$ & $75 \%$ \\
\hline
\end{tabular}

和光園では鬼眼症の患者は半分の $25 \%$ でしかなかった。 又表VII，表VIに示される様に，結節型，神斑型に分けた 鬼眼頻度においてもこの傾向は同様であった。（麻疩性 鬼眼のみで瘢痕性鬼眼は含んでいない。）

表VII 結 節 型の 鬼眼 頻 度

\begin{tabular}{|c|c|c|c|c|}
\hline & 栥泉園 & 敬 愛 園 & 和 光 園 \\
\hline \multirow[t]{2}{*}{ 両 } & $5 \mathrm{~m} \mathrm{~m} \downarrow$ & $18 \%$ & $13 \%$ & $6 \%$ \\
\hline & $6 \sim 10 \mathrm{~m} \mathrm{~m}$ & $13 \%$ & $9 \%$ & $7 \%$ \\
\hline 側 & $11 \mathrm{~mm} \uparrow$ & $1 \%$ & $1 \%$ & $1 \%$ \\
\hline \multirow[t]{2}{*}{ 片 } & $5 \mathrm{~m} \mathrm{~m} \downarrow$ & $15 \%$ & $12 \%$ & $9 \%$ \\
\hline & $6 \sim 10 \mathrm{~m} \mathrm{~m}$ & $2 \%$ & $3 \%$ & $0 \%$ \\
\hline \multirow[t]{2}{*}{ 侧 } & $11 \mathrm{~m} \mathrm{~m} \uparrow$ & $0 \%$ & $0 \%$ & $0 \%$ \\
\hline & 健 & $51 \%$ & $62 \%$ & $77 \%$ \\
\hline
\end{tabular}

表䜣 神 斑 型の鬼眼頻度

\begin{tabular}{|c|c|c|c|c|}
\hline & 楽泉園 & 敬 愛 園 & 和 光 園 \\
\hline \multirow[t]{2}{*}{ 両 } & $5 \mathrm{~m} \mathrm{~m} \downarrow$ & $11 \%$ & $14 \%$ & $8 \%$ \\
\hline & $6 \sim 10 \mathrm{~m} \mathrm{~m}$ & $13 \%$ & $13 \%$ & $8 \%$ \\
\hline 側 & $11 \mathrm{~mm} \uparrow$ & $0 \%$ & $1 \%$ & $1 \%$ \\
\hline \multirow[t]{2}{*}{ 片 } & $5 \mathrm{~mm} \downarrow$ & $14 \%$ & $6 \%$ & $7 \%$ \\
\hline & $6 \sim 10 \mathrm{~m} \mathrm{~m}$ & $2 \%$ & $3 \%$ & $1 \%$ \\
\hline \multirow[t]{2}{*}{ 側 } & $11 \mathrm{~mm} \uparrow$ & $0 \%$ & $0 \%$ & $0 \%$ \\
\hline & 健 & $60 \%$ & $63 \%$ & $75 \%$ \\
\hline
\end{tabular}

6) 们膜混濁頻度 鿇膜炎既往症と比例する传膜混 濁頻度（怪度の瀬性パンヌスは除外した）も，表IXに示 される様に，楽泉園と和光園とでは，10\%の遙いがあ り，敬愛園はその中間に位した。
表IX 角膜混濁頻度（眼数）

\begin{tabular}{|c|c|c|c|}
\hline & 楽泉 園 & 敬愛 園 & 和 光 園 \\
\hline 健 & $77 \%$ & $81 \%$ & $87 \%$ \\
\hline 軽度混濁 & $15 \%$ & $13 \%$ & $9 \%$ \\
\hline 中等度混濁 & $4 \%$ & $3 \%$ & $2 \%$ \\
\hline 高度混濁 & $4 \%$ & $3 \%$ & $2 \%$ \\
\hline
\end{tabular}

7 ）視力障害者頻度 以上の障害が総合された結果の 視力障害者も, 当然ではあるが表Xの様に, 北方患者の 万が多くなっていた。

表X 視力障害者頻度

\begin{tabular}{ll|r|r|r}
\hline & & 楽宗園 & 敬愛園 & 和 光 園 \\
\hline 健 & 全 & $69.4 \%$ & $77.2 \%$ & $90.9 \%$ \\
1 & 級 & $14.1 \%$ & $10.2 \%$ & $5.4 \%$ \\
2 & 級 & $3.3 \%$ & $3.3 \%$ & $2.2 \%$ \\
3 & 級 & $2.4 \%$ & $1.5 \%$ & $0.6 \%$ \\
4 & 級 & $2.3 \%$ & $0.7 \%$ & $0.3 \%$ \\
5 & 級 & $2.9 \%$ & $3.0 \%$ & $0.3 \%$ \\
6 & 級 & $5.6 \%$ & $3.1 \%$ & $0.3 \%$ \\
\hline
\end{tabular}

II. 敬愛園及び和光園入園中の奄美群息出身患者につい ての比較

1 ）対象虫者 敬愛園入園中の 130 名, 及び和光園入 園中の 222名の奄美群自讪身者について行なった。

2) 病型別 表XIの様に, 和光園入園患者の方に結節 型が多かった。

表XI 大皂郡出身者病型別

\begin{tabular}{|c|c|c|}
\hline & 敬 愛 園 & 和 光 園 \\
\hline 結 節 型 & $41 \%$ & $57 \%$ \\
\hline 斑 紋 型 & $18 \%$ & $8 \%$ \\
\hline 神 経 型 & $41 \%$ & $35 \%$ \\
\hline
\end{tabular}

3）結節型患者の眉毛脱落頻度 表X川の様に，和光園 入園患者の方が多かったが，乙れは他の眼症状とは逆の 結果になっている。

表XII 大島郡出身者眉毛脱落頻度

\begin{tabular}{cc|c|c}
\hline & & 敬 愛 園 & 和 光 園 \\
\hline 脱 & 落 & $23 \%$ & $30 \%$ \\
粗 & 鬆 & $4 \%$ & $27 \%$ \\
健 & 全 & $73 \%$ & $43 \%$ \\
\hline
\end{tabular}

4）結節型患者の葡萄膜炎及び併発性白内障頻度 表 Xn及び表XIII如く，葡萄膜炎，併発性白内障共に，敬愛 


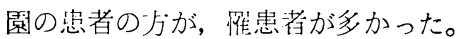

表XIII 大島郡!身者茂芽膜炎频度

\begin{tabular}{|c|c|c|}
\hline & 敬 愛 園 & 和 光 跑 \\
\hline 惟 & $60 \%$ & $50 \%$ \\
\hline 未 躍 忠 & $40 \%$ & $50 \%$ \\
\hline
\end{tabular}

表XIV 大島郡!身者併発性白内障頻度 (服数)

\begin{tabular}{|c|c|c|}
\hline & 敬愛園 & 和 光 園 \\
\hline 白 内 障 & $14 \%$ & $11 \%$ \\
\hline 健 & $86 \%$ & $89 \%$ \\
\hline
\end{tabular}

5 ）鬼眼頻度 表XVの㥞に鬼眼も又, 和光園の垫者に 健全な者が多かった。

表XV 大泉郡仙身者鬼眼频度

\begin{tabular}{cc|c|c}
\hline & & 敬 愛園 & 和 光 園 \\
\hline 両 & 侧 & $22 \%$ & $17 \%$ \\
片 & 侧 & $7 \%$ & $8 \%$ \\
健 & 全 & $71 \%$ & $75 \%$ \\
\hline
\end{tabular}

6）角膜混濁頻度 表XVIの様に, 矢張り和光園の患者 に健全な者が多かった。

表XVI 大島郡出身者角膜混濁頻度（眼数）

\begin{tabular}{|c|c|c|}
\hline & 敬 愛 園 & 和 光 園 \\
\hline 健 全 & $85 \%$ & $87 \%$ \\
\hline 軽度 混濁 & $13 \%$ & $9 \%$ \\
\hline 中等度混濁 & $1 \%$ & $2 \%$ \\
\hline 高度 混 䋧 & $1 \%$ & $2 \%$ \\
\hline
\end{tabular}

\section{考察}

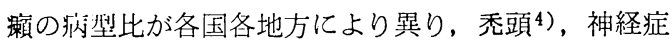
状 ${ }^{5)}$ ，眼症状6)等もそれにつれて怪重に相当な差がある 事は広く知られている。林1)は甶界各地の瀨施設を視察 し，気候が攋に種々の影響を及ぼす事を知り攋気候説を 述べたが, 光田 ${ }^{2}$ 嫶沼 3 ）も南方に行く程癩症が軽くなる 事を報告している。

偶々著者は, それぞれ気候の異なる三瀬療荃所（草津 楽泉園, 星塚敬愛園, 奄美和光園）において, 約 1 力年 半ずつ眼科を扣当し，その地の気侯が瀨症状，特にその 眼症状に如何なる影響を及ぼすかを観察した。その成績 は表IIIから表Xに示したごとく，北方より南方の療養所
患者のうが全ての峎症状共怪度であり，従って狊人数む 南方へ行く程減少していた。

先ず, 表而の届毛について考察すると, 和光園琹者の 回毛仪全考百分率は, 栥察園思者のそれの 2 倍にも達す る。その上, 南方においては生米㞓毛が濃く, 瀨性脱落 も弱いのでその粗影者の多くは一見脱落を気付かれにく く, 為に眉毛脱落率の南北差は, 実際より更に大きく感 じら机る。

林11)7)はインド，アフリカ等の癩隹者には虬彩炎を殆 んど見ず，失明者も極めて少いと報告しているが，我が

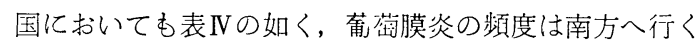
程減少している。又葡茼膜炎の結果たる併発性白内障患 者もそれにつれ南方程少なくなっている。

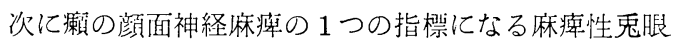
む, 居毛, 虬彩炎等と同様南方程䍜患者数が減少し, 同 時にその䏩裂開大度も怪度になっている。兔腿の頻度に ついて塭沼8)は, 神経瀨には結節瀨に比し高率に出現す ると述べているが, 今回の成續では逆に，結節型により 高率に出現している。これはスルフォン剂使用の結果, 麻瘏が強く発生する重症結節濑想者の寿:命が顕著に延長 した事にその主要な原因があると嗯われる。

林 $\left.{ }^{1}\right)$ は, 敬愛園入園者についてその出身地別に病状の

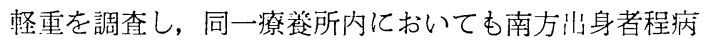
状が怪度であると就告したが, 今回著者は, 苒美群島出 身者が南 (和光園) 北（敬愛園）療養所に別れ住んだ場 合，その眼症状に差が止ずるか否かを調査した。結果は 表XIから表XVIに示した如く，㞓毛を除いては全ての眼症 状共, 北方の敬愛園に移住した者の方がより重症であっ た。

以上の事実加ら, 瀬の種々の症状は, 南方居住者程軽 度になっている事が理解されるが, 草津楽泉園が緯度の 上ではさ程北偏していないにも拘わらず，1,200m の高 地に設けられている為癩の症状が他の療笭所に比し, か なり重篤である事, 及び，林1) の報告にあるジャワの ペラントガン療誉所（1,000 呎の高地に位置する）の虹 彩炎の多発等の事笋は, 感冷の癩に対する悪影響を示す むのである。かって光田は, 南方程榎症状の怪くなる事 に注目し, 療養所北守南進論を述べたが, 㿎の治療に際 しては，その症状及び経過に気候が重大な影響を及ぼし ている事実に常に考虑を払うべきであろう。

\section{結論}

栗生楽沓園, 星塚敬愛園及び奄美和光園の入園忠者に

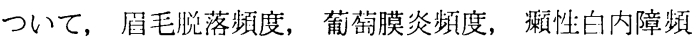


度, 鬼眼頻度, 角膜湿蚫頻度, 視力障客者頻度等を此較 し次の如き結柴を得た。

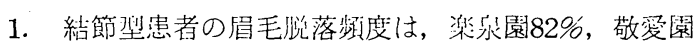
$65 \%$ ，和光園56\%であった。

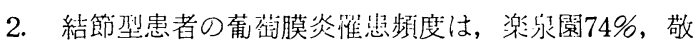
愛園66\%, 和光園47\%であった。

3. 結節型忽者の併発性白内障頻度 (腿数) は, 染灾嘻 $23 \%$ ，敬愛園20\%，和光園11\%であった。

4. 仵膜注濁頻度(眼数)は, 楽泉園 $23 \%$, 敬愛園 $19 \%$, 和光園 $13 \%$ であった。

5. 鬼眼頻度は，滜㲾園47\%，敬愛園38\%，和光園 $25 \%$ であった。

6. 鬼眼は神斑型より結節型により频度が高かった。

7. 和光園及び敬愛園の大鼠郡出身患者の眼症状を比較 した所, 和光園の患者の方が軽症であった。

8. 以上の如く, 北方より南方の潦養所の患者程眼症状 が怪く, 又同一地出身者であ南方に居住する者の方が 侵態が怪度であった。
文献

1) 林文雄: 䫐気候説, 東京医事新誌, 3116, 2(41939),

2) 光旧健輔：南方に行くほど瀨症怪るし、レプラ,

15, 244 (1944)

3 ) 睢沼英之助: The climate theory in leprosy,

Internat. J. Leprosy, 6, 315 (1938)

4 ）永井健児：愛生園およで敬愛園における権性秃頭の 統計的観察なびに秃頭度比皎による文侯説，レプラ， 8, 301 (1937)

5 ) 前田てい: 攋の神経症状と気候説, レプラ，9，431 (1938)

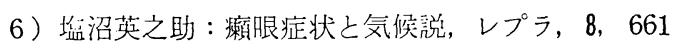
(1937)

7 ) 林文雄: Report of a leprosy study tour, Int ernat。

J. Leprosy, 3, 165 (1935)

8 ）湓沼英之助：日本眼科全書 12 巻，42（1953） 